\title{
FAKTOR YANG MEMPENGARUHI PERILAKU ANGGOTA KELOMPOK USAHA WARUNG SEJAHTERA PADA PENERAPAN DIGITAL MARKETING
}

\author{
Nurul Huda ${ }^{1}$, Sri Chusri Haryanti ${ }^{2}$, Nova Rini ${ }^{3}$, Rosmelani ${ }^{4}$ \\ ${ }^{1}$ Magister Manajemen, Universitas YARSI \\ ${ }^{2}$ Fakultas Teknik, Universitas YARSI \\ ${ }^{3}$ STIE Muhammadiyah Jakarta \\ ${ }^{4}$ Yayasan OASE Anak Bangsa \\ Email :pakhuda@yahoo.com
}

\begin{abstract}
ABSTRAK
Para pelaku usaha warung yang tergabung dalam Kelompok Usaha Warung Sejahtera mengalami dampak negative selama pandemic covid 19 berupa penurunan pendapatan. Tujuan kegiatan pengabdian pada masyarakat ini berupa penggunaan digital marketing yang meningkat dan pendapatan para pengusaha warung di kelompok usaha warung sejahtera mengalami peningkatan. Metode pengabdian berupa pendampingan dalam bentuk pelatihan dan pengukuran perilaku menggunakan metode SEM dengan software SmartPLS. Hasil kegiatan pengabdian masyarakat ini berupa intensi dan perilaku anggota kelompok usaha warung sejahtera menggunakan digital marketing dalam jalanin usaha. Intensi dan perilaku anggota Kelompok Usaha Warung Sejahtera cukup tinggi untuk menerapkan atau menggunakan digital marketing dalam meningkatkan pendapatan. Hal ini terlihat dari hasil uji hipotesis yang signifikan antara pengaruh pengetahuan dan sikap secara tidak langsung terhadap perilaku melalui variabel intensi pelaku usaha warung.
\end{abstract}

Kata Kunci : Perilaku, Usaha Warung, Pengetahuan, Sikap, Intensi

\section{PENDAHULUAN}

Pengusaha warung termasuk kategori usaha mikro dan sector ekonomi informal (Adhania, 2017; Dewi et al., 2014; Imron \& Wibowo, 2008; Ompusunggu \& Djawahir, 2014). Masa pandemic covid-19 saat ini membuat para pengusaha warung harus berinovasi, sehingga dapat bertahan dan meningkatkan pendapatan.

Berbagai macam strategi bisa dilakukan oleh para pengusaha warung, salah satunya adalah menerapkan $e$ commerce pada strategi pemasaran. Hal ini sesuai dengan hasil riset Hardilawati (2020), bahwa strategi bertahan untuk UKMK berupa melakukan perdagangan secara e-commerce, melakukan pemasaran secara digital, melakukan perbaikan kualitas produk dan penambahan layanan serta menjalin dan mengoptimalkan hubungan pemasaran pelanggan.

Penelitian Awali \& Rohmah (2020) juga membuktikan bahwa $e$ marketing memberikan dampak positif ditengah pandemi Covid 19 pada ketahanan ekonomi UMKM. Kondisi 
ini membuat Program Studi Magister Manajemen Universitas YARSI mengadakan kegiatan pengabdian pada masyarakat mengenai e-marketing atau digital marketing untuk pengusaha warung wilayah DKI Jakarta.

Mitra kegiatan pengabdian pada masyarakat ini adalah Kelompok Usaha Warung Sejahtera yang berlokasi di Kelurahan Sungai Bambu Kecamatan Tanjung Priok Jakarta Utara. Kelompok Usaha Warung Sejahtera merupakan kelompok yang memiliki anggota para pengusaha warung dengan berbagai macam produk yang dijual. Produk tersebut berupa makanan, minuman, pakaian dan aksesoris. Semua anggota nya termasuk usaha skala mikro.

Penggunaan digital marketing pada para anggota kelompok usaha warung sejahtera belum optimal. Ketidakoptimalan tersebut tidak hanya pada para anggota kelompok usaha warung namun juga para pengurus kelompok usaha tersebut. Kondisi ini sesuai dengan penelitian yang dilakukan Hanoatubun (2020) bahwa partisipasi masyarakat dalam perekonomian khususnya kelompok muda, perempuan dan UMKM dipandang belum optimal pada perkembangan teknologi saat ini.
Kegiatan pengabdian pada masyarakat ini berupa kegiatan pemberian pelatihan kepada para pengurus dan anggota Kelompok Usaha Warung Sejahtera. Pelatihan ini difokuskan kepada penggunaan digital marketing. Tujuan dari kegiatan pengabdian pada masyarakat ini berupa penggunaan digital marketing yang meningkat dan pendapatan para pengusaha warung di kelompok usaha warung sejahtera mengalami peningkatan.

Pengukuran terhadap pelatihan dan workshop tersebut diukur menggunakan teori perilaku. Perilaku yang ditampilkan oleh setiap individu sangatlah beragam dan unik termasuk perilaku pengusaha warung. Keberagaman dan keunikan tersebut menarik perhatian para ahli untuk meneliti tentang perilaku manusia. Terdapat banyak teori yang menjelaskan tentang determinan perilaku manusia. Teori-teori perilaku tersebut para ahli memaparkan pendapatnya tentang bagaimana suatu perilaku terbentuk dan faktor apa saja yang mempengaruhi. (Mahyarni, 2013).

Banyak faktor atau variabel yang dapat mempengaruhi perilaku manusia. Faktor-faktor tersebut adalah 
Pengetahuan, Sikap, dan Intensi (Ajzen, 1991; Ajzen \& Fishbein, 1977; Conner \& Norman, 2005; Kurniaputri et al., 2020)

Pengetahuan menurut Kamus Cambridge University merupakan pemahaman terhadap sebuah informasi atau subjek yang didapatkan dari pengalaman atau proses pembelajaran. (Purnama et al., 2020). Pelatihan atau workshop dapat meningkatkan pengetahuan seperti hasil kegiatan pengabdian masyarakat Huda et al. (2020); Huda \& Nazwirman (2018); dan Huda et al. (2018). Pelatihan maupun workshop merupakan proses pembelajaran, sehingga pengetahuan para responden dalam penelitian ini diperoleh setelah mengikuti pelatihan selama program kegiatan pada masyarakat.

Sikap menurut Ajzen (1991) merupakan derajat mana seseorang memiliki penilaian evaluasi menguntungkan atau tidak menguntungkan dari perilaku dalam sebuah pertanyaan. Ajzen (1991) juga mengemukakan bahwa sikap terhadap perilaku ini ditentukan oleh keyakinan yang diperoleh mengenai konsekuensi dari suatu perilaku atau disebut juga behavioral beliefs.
Kurniaputri et al. (2020) mengungkapkan bahwa intensi merupakan perubahan yang paling dekat dengan perilaku yang dilakukan oleh individu, dan merupakan perubahan yang menjembatani antara sikap dan perilaku nyata. Venkatesh et al. (2003) mendefinisikan intensi sebagai ketertarikan seseorang menggunakan atau membeli sesuatu. Venkatesh et al. (2003) juga meyakini bahwa intensi memiliki pengaruh yang positif signifikan terhadap perilaku individu dalam menggunakan teknologi. Hal ini sesuai dengan kegiatan pengabdian masyarakat ini bahwa perilaku usaha warung pada penggunaan teknologi dipengaruhi oleh intensi.

Pengetahuan dan sikap dapat mempengaruhi niat atau intensi seseorang dalam mengambil sebuah keputusan. (Ajzen, 1991; Huda et al., 2012; Kurjono \& Setiawan, 2020). Sehingga berdasarkan uraian diatas, maka gambaran pemikiran dalam penelitian ini terlihat pada Gambar 1 berikut. 


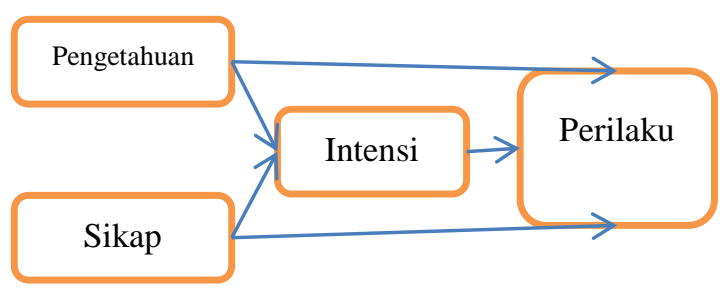

Gambar 1. Kerangka Pemikiran

Berdasarkan gambar kerangka pemikiran diatas, maka hipotesis yang dikembangkan dalam penelitian ini adalah:

$\mathrm{H}_{1}$ : Pengetahuan pelaku usaha warung mengenai teknologi berpengaruh positif secara langsung terhadap Intensi

$\mathrm{H}_{2} \quad$ : Sikap pelaku usaha warung berpengaruh positif secara langsung terhadap intensi

$\mathrm{H}_{3} \quad$ : Intensi pelaku usaha warung berpengaruh positif secara langsung terhadap perilaku

$\mathrm{H}_{4}$ : Pengetahuan pelaku usaha warung berpengaruh positif secara langsung terhadap perilaku

$\mathrm{H}_{5} \quad$ : Sikap pelaku usaha warung berpengaruh positif secara langsung terhadap perilaku

$\mathrm{H}_{6}$ : Pengetahuan dan Sikap berpengaruh positif secara tidak langsung terhadap Perilaku melalui Intensi

\section{METODE PELAKSANAAN}

Rancangan kegiatan ini dengan melakukan pendampingan khususnya dalam penggunaan teknologi untuk meningkatkan omset penjualan anggota kelompok usaha warung sejahtera. Pengukuran perubahan perilaku pelaku usaha warung menggunakan rancangan kegiatan kuantitatif dengan melihat perilaku pelaku usaha warung dari variabel pengetahuan, sikap, dan intensi.

Objek dalam kegiatan ini adalah pengetahuan, sikap, intensi, dan perilaku para pelaku usaha warung yang tergabung dalam Kelompok Usaha Warung Sejahtera.

Bahan dan alat utama dari kegiatan ini berupa aplikasi WA Business dan website. Pengetahuan pelaku usaha warung melalui kegiatan pelatihan/workshop melalui media online zoom. Pelatihan tersebut diadakan sebanyak 3 kali.

Tempat kegiatan di Jalan Sungai Bambu IV no. 20 RT 006 RW 08 Kelurahan Sungai Bambu, Kecamatan Tanjung Priok Jakarta Utara.

Populasi dalam kegiatan ini adalah anggota kelompok usaha warung sejahtera sebanyak 36 orang. Oleh karena jumlah populasi kurang dari 100 
orang, maka data dalam penelitian ini menggunakan data populasi yaitu sebanyak 36 responden. Hal ini sesuai dengan pendapat Danim (2007) bahwa populasi kurang dari 100, maka lebih baik menggunakan data seluruh populasi untuk dijadikan sampel dan diolah. Teknik pengumpulan data berupa kuesioner dan wawancara.

Variabel pengetahuan dalam penelitian ini merupakan tingkat pengetahuan pelaku usaha warung setelah mengikuti pelatihan dengan indikator : pengetahuan produk, pembelian, dan pemakaian. Variabel sikap dalam penelitian ini merupakan suatu faktor predisposisi atau faktor yang ada dalam diri seseorang yang dipelajari untuk memberikan respon dengan cara yang konsisten, yaitu suka atau tidak suka pada penilaian terhadap suatu objek yang diberikan. Variabel sikap diukur dengan indikator : cognitive component, affective component, dan behavioral component. (Simamora, 2002). Variabel intensi dalam penelitian ini merupakan kekuatan utama yang menjadi sumber motivasi seseorang untuk bertingkah laku tertentu. Indikator yang digunakan untuk mengukur variabel intensi : faktor pribadi, faktor social, dan informasi.
Variabel perilaku dalam penelitian ini merupakan studi bagaimana tentang individu, kelompok, dan organisasi memilih, membeli, menggunakan, dan bagaimana barang, jasa, ide atau pengalaman untuk memuaskan kebutuhan dan keinginan mereka. Indikator yang digunakan dalam mengukur variabek perilaku pelaku usaha warung, berupa : Prinsip moralitas, Prinsip kemurahan hati, dan Prinsip kesederhanaan.

Teknik analisis yang digunakan adalah teknik Struktural Equation Model (SEM), hal ini berkaitan adanya pengaruh langsung dan tidak langsung. Software yang digunakan adalah Smart PLS versi 2.0m. Ghozali (2005) menjelaskan bahwa PLS adalah metode analisis yang bersifat soft modeling karena tidak mengasumsikan data harus dengan pengukuran skala tertentu, yang berarti jumlah sampel dapat kecil (dibawah 100 sampel).

\section{HASIL DAN PEMBAHASAN}

Gambaran umum para anggota kelompok usaha warung sejahtera yang jadi mitra dalam kegiatan pengabdian masyarakat ini terlihat pada tabel 1 berikut. 
Tabel 1. Demografi Responden

\begin{tabular}{|c|c|c|c|}
\hline & & Jumlah & $\begin{array}{c}\text { Persentase } \\
(\%)\end{array}$ \\
\hline \multirow{2}{*}{$\begin{array}{c}\text { Jenis } \\
\text { Kelamin }\end{array}$} & Pria & 3 & 8.3 \\
\hline & Wanita & 33 & 91.7 \\
\hline \multirow[t]{4}{*}{ Usia } & $20-<25$ th & 1 & 2.8 \\
\hline & $25-<35$ th & 2 & 5.6 \\
\hline & $35-50$ th & 30 & 83.3 \\
\hline & $>50$ th & 3 & 8.3 \\
\hline \multirow{4}{*}{$\begin{array}{c}\text { Pendapatan } \\
\text { Sebelum } \\
\text { Pandemi } \\
\text { Covid } 19\end{array}$} & $<\mathrm{Rp} 500.000$ & 5 & 13.9 \\
\hline & $\begin{array}{l}\text { Rp } 500.000-<1 \\
\text { juta }\end{array}$ & 12 & 33.3 \\
\hline & 1 juta $-<1,5$ Juta & 11 & 30.6 \\
\hline & $>2$ juta & 8 & 22.2 \\
\hline \multirow{4}{*}{$\begin{array}{c}\text { Pendapatan } \\
\text { selama } \\
\text { pandemic } \\
\text { covid } 19\end{array}$} & $<\mathrm{Rp} 500.000$ & 19 & 52.8 \\
\hline & $\begin{array}{l}\text { Rp } 500.000-<1 \\
\text { juta }\end{array}$ & 11 & 30.6 \\
\hline & 1 juta $-<1,5$ Juta & 2 & 5.6 \\
\hline & $>2$ juta & 4 & 11.1 \\
\hline \multirow{3}{*}{$\begin{array}{c}\text { Status } \\
\text { Pernikahan }\end{array}$} & Menikah & 24 & 66.7 \\
\hline & Belum Menikah & 1 & 2.8 \\
\hline & Duda/Janda & 11 & 30.6 \\
\hline \multirow{5}{*}{$\begin{array}{c}\text { Pendidikan } \\
\text { Terakhir }\end{array}$} & SD & 4 & 11.1 \\
\hline & SMP & 7 & 19.4 \\
\hline & SMA/SMK & 20 & 55.6 \\
\hline & Diploma (D1-D3) & 2 & 5.6 \\
\hline & S1 atau D4 & 3 & 8.3 \\
\hline \multirow[t]{5}{*}{$\begin{array}{c}\text { Jenis } \\
\text { Usaha }\end{array}$} & $\begin{array}{l}\text { Makanan kecil } \\
\text { kering }\end{array}$ & 1 & 2.8 \\
\hline & $\begin{array}{l}\text { Makanan } \\
\text { kecil/jajanan }\end{array}$ & 11 & 30.6 \\
\hline & Makanan Warung & 4 & 11.1 \\
\hline & Pakaian/Aksesoris & 5 & 13.9 \\
\hline & Lainnya & 15 & 41.7 \\
\hline
\end{tabular}

Sumber : Hasil pengolahan data, 2020

Pelaku usaha warung yang mengikuti pelatihan terdiri dari 3 orang berjenis kelamin Pria $(8,3 \%)$ dan 33 orang berjenis kelamin wanita $(91,7 \%)$. Hasil ini menunjukkan bahwa para pelaku usaha warung mayoritas dijalani oleh wanita. Mayoritas wanita yang menjalani usaha warung sesuai dengan penelitian Mutmainah (2020) bahwa kegiatan ekonomi yang mungkin dilakukan oleh wanita adalah pada sektor Usaha Mikro Kecil dan Menengah (UMKM). 
Usia para pelaku usaha warung dalam kegiatan pengabdian masyarakat ini paling banyak berusia diantara 35 50 tahun yaitu sebanyak 30 responden $(83,3 \%)$. Pelaku usaha warung ada yang berusia diatas 50 tahun, namun hanya 3 orang $(8,3 \%)$.

Pelaku usaha warung sebanyak 36 orang dalam kegiatan pengabdian masyarakat memiliki pendapatan tertinggi sebesar lebih dari Rp 2 juta sebelum pandemic covid 19, namun hanya sebanyak 8 orang $(22,2 \%)$. Ratarata pendapatan pelaku usaha warung sebelum terjadinya pandemic covid 19 antara Rp 500.000 sampai $<$ Rp 1 juta yaitu sebanyak 12 orang $(33,3 \%)$. Pelaku usaha warung yang memiliki pendapatan antara Rp 1 juta sampai < Rp 1,5 juta juga banyak yaitu sebanyak 11 orang $(30,6 \%)$.

Pandemic covid 19 berdasarkan tabel 1 di atas memberi efek yang sangat besar terhadap pendapatan para pelaku usaha warung. Pendapatan pelaku usaha warung < Rp 500.000 meningkat selama masa pandemic covid 19. Sebelum pandemic covid 19 terjadi, pelaku usaha warung yang memiliki pendapatan $<\operatorname{Rp} 500.000$ hanya 5 orang $(13,9 \%)$, namun selama pandemic covid
19 meningkat menjadi sebanyak 19 orang $(52,8 \%)$. Hasil ini menunjukkan penambahan pelaku usaha warung yang berpendapatan < Rp 500.000 sebesar $73,7 \%$.

Mayoritas pelaku usaha warung memiliki status sudah menikah yaitu sebanyak 24 orang $(66,7 \%)$. Pelaku usaha warung yang memiliki status sebagai Duda/Janda juga banyak yaitu sebesar $39,6 \%$.

Pelaku usaha warung dalam Kelompok Usaha Warung Sejahtera memiliki pendidikan terakhir sampai tingkat SMA/SMK sebanyak 20 orang $(55,6 \%)$. Jenis usaha yang dijalani para pelaku usaha warung ini kebanyakan adalah jenis usaha lainnya selain pilihan yang diberikan dalam kuesioner. Selain jenis usaha lainnya, jenis usaha makanan kecil/jajanan juga banyak dilakukan oleh para pelaku usaha warung yaitu sebanyak 11 orang $(30,6 \%)$.

Deskripsi Pengetahuan, Sikap, Intensi, dan Perilaku Pengusaha Warung

Tingkat pengetahuan pelaku usaha warung mengenai digital marketing setelah mengikuti pelatihan terlihat pada tabel 2 berikut. 
Tabel 2. Deskripsi Tingkat Pengetahuan Pelaku Usaha Warung

\begin{tabular}{l}
\hline \multicolumn{1}{c}{ Indikator } \\
\hline Responden \\
mengetahui digital \\
marketing berupa wa \\
business, website, \\
media social, dll. \\
\hline Responden bisa \\
mengetahui d, \\
menggunakan digital \\
marketing untuk \\
memasarkan produk \\
usaha \\
\hline Responden \\
mengetahui \\
penggunaan wa \\
business, website, \\
media sosial dapat \\
meningkat penjualan \\
usaha warung \\
\hline Sumber Hasil Pengolahan Data, 2020
\end{tabular}

Sumber : Hasil Pengolahan Data, 2020

Tabel 2 menunjukkan bahwa tingkat pengetahuan pelaku usaha warung paling tinggi untuk tingkat pengetahuan bahwa digital marketing berupa wa business, website, media sosial, dan lain-lain. Hal ini karena rata-rata nilai skor tingkat pengetahuan tersebut sebesar 3,03 lebih tinggi daripada tingkat pengetahuan mengenai manfaat digital marketing dapat meningkatkan penjualan dan menjadi bentuk pemasaran produk. Hasil ini menunjukkan bahwa manfaat digital marketing untuk pemasaran dan peningkatan penjualan masih belum banyak diketahui oleh para pelaku usaha warung khususnya yang tergabung dalam kelompok usaha warung sejahtera.

Sikap para pelaku usaha warung setelah mengikuti pelatihan digital marketing terlihat pada tabel 3 .

Tabel 3. Deskripsi Tingkat Sikap Pelaku Usaha Warung

\begin{tabular}{|c|c|}
\hline Indikator & Mean \\
\hline $\begin{array}{l}\text { Digital marketing } \\
\text { melalui wa business, } \\
\text { website, media } \\
\text { sosial, efisien dan } \\
\text { efektif } \\
\text { responden sebagai }\end{array}$ & 2,94 \\
\hline
\end{tabular}




\begin{tabular}{l}
\hline pengusaha warung \\
Selama ini \\
responden \\
menginginkan \\
penjualan melalui \\
wa business, \\
website, media sosial \\
Responden akan \\
selalu menerapkan \\
digital marketing \\
melalui wa business, \\
website, media sosial \\
\hline \multicolumn{2}{l}{ Sumber : Hasil Pengolahan Data, 2020 }
\end{tabular}

Pelaku usaha warung dalam kegiatan pengabdian masyarakat ini memiliki sikap cukup positif mengenai digital marketing melalui wa business, website dan media sosial adalah efektif dan efisien bagi pelaku usaha warung. Hal ini dilihat dari nilai rata-rata skor sebesar 2,94 jika dibulatkan menjadi skor 3 yang artinya positif dalam menanggapi digital marketing sesuatu yang efisien dan efektif untuk usaha warung. Pelaku usaha warung juga selama ini menginginkan digital marketing untuk pemasaran produk dan akan selalu menerapkan digital marketing. Namun untuk sikap penerapan digital marketing ini belum secara penuh, hal ini dilihat dari nilai rata-rata skor 2,88 lebih rendah daripada indikator sikap yang lain.

Intensi pelaku usaha warung terhadap penggunaan digital marketing terlihat pada tabel 4.

Tabel 4. Deskripsi Tingkat Intensi Pelaku Usaha Warung

\begin{tabular}{l}
\hline \multicolumn{2}{c}{ Indikator } & Mean \\
\hline Responden akan \\
melakukan penjualan \\
menggunakan WA \\
business, website, \\
media sosial karena \\
efisien dan efektif \\
\hline Responden akan \\
melakukan penjualan \\
melalui 2,77 \\
business, Website, \\
media sosial karena \\
mampu melakukan \\
digital marketing \\
\hline
\end{tabular}




\begin{tabular}{l}
\hline Responden akan \\
melakukan penjualan \\
melalui 2,94 \\
business, website, \\
media sosial karena \\
akan meningkatkan \\
penjualan usaha \\
warung
\end{tabular}

Sumber : Hasil Pengolahan Data, 2020

Nilai rata-rata skor intensi pelaku usaha warung menunjukkan intensi yang cukup besar untuk penggunaan digital marketing dalam memasarkan produk warung.
Intensi yang cukup besar tersebut juga akan menggambarkan perilaku pelaku usaha warung dalam melaksanakan digital marketing.

Tabel 5. Deskripsi Tingkat Perilaku Pelaku Usaha Warung

\begin{tabular}{|c|c|}
\hline Indikator & Mean \\
\hline $\begin{array}{l}\text { Responden akan } \\
\text { melakukan penjualan } \\
\text { melalui WA } \\
\text { business, website, } \\
\text { media sosial karena } \\
\text { sudah sesuai dengan } \\
\text { masa pandemic } \\
\text { covid 19 saat ini }\end{array}$ & 2,97 \\
\hline $\begin{array}{l}\text { Responden akan } \\
\text { melakukan penjualan } \\
\text { melalui } \\
\text { business, website, } \\
\text { media sosial karena } \\
\text { memberi manfaat } \\
\text { yang besar bagi } \\
\text { usaha warung }\end{array}$ & 2,92 \\
\hline $\begin{array}{l}\text { Responden akan } \\
\text { melakukan penjualan } \\
\text { melalui WA } \\
\text { business, website, } \\
\text { media sosial karena } \\
\text { prosesnya yang } \\
\text { efisien dan efektif }\end{array}$ & 2,94 \\
\hline
\end{tabular}

Tabel 5 menunjukkan nilai ratarata skor tingkat perilaku pelaku usaha warung dalam penggunaan digital marketing. Nilai rata-rata skor tingkat 
perilaku ini tidak ada yang mencapai nilai 3, namun jika dibulatkan akan menjadi nilai rata-rata skor sebesar 3 . Hasil ini menunjukkan tingkat perilaku pelaku usaha warung adalah cukup positif dalam mengaplikasikan digital marketing melalui wa business, website dan media sosial.

\section{Hasil Uji Realibilitas dan Validitas Model}

Uji Reliabilitas indikatorindikator dalam mengkonstruk variabel penelitian dilakukan dengan mengolah data menggunakan software SmartPLS versi $2.0 \mathrm{~m}$.

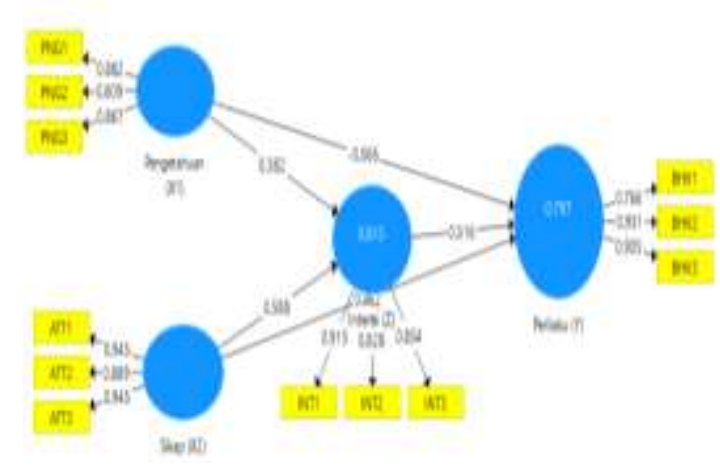

Gambar 2. Nilai Outer Loading

Sumber : Hasil pengolahan data, 2020

Gambar 2 menunjukkan semua indikator dalam penelitian ini memiliki nilai loading faktor lebih besar dari 0,5 . Hasil ini berarti bahwa indikatorindikator yang digunakan adalah reliable dalam mengkonstruk variabel penelitian. Menurut Wong (2013) nilai outer loading sebesar 0,50 termasuk hubungan yang moderate, jika lebih dari 0,50 mencapai 0,75 memiliki hubungan yang substantive, sementara jika kurang dari 0,50 mencapai 0,25 memiliki hubungan yang lemah.

Uji reliabilitas setiap variabel dilihat juga dari Internal Consistency Variabel pada nilai cronbach's alpha. Nilai cronbach's alpha dari output SmartPLS untuk setiap variabel lebih dari 0,75. Hasil ini menunjukkan bahwa indikator-indikator yang digunakan untuk mengukur variabel penelitian adalah indikator yang baik. Wong (2013) menyatakan bahwa nilai uji realibilitas lebih dari 0,6 sudah menunjukkan hasil yang dapat diterima.

Uji validitas dilihat dari nilai convergent validity dan discriminant validity. Nilai kedua item tersebut terlihat pada nilai Average Variance Extracted (AVE) setiap variabel. Hasil pengolahan data menunjukkan bahwa nilai AVE pada convergent validity untuk semua variabel lebih besar dari 0,5. Nilai AVE pada discriminant validity untuk semua variabel memiliki hubungan yang lebih besar daripada hubungan antar variabel. Data-data tersebut menunjukkan bahwa semua indikator dalam penelitian ini valid 
dalam mengkonstruk variabel-variabel yang diteliti.

Evaluasi Goodness of fit model penelitian diukur dengan menggunakan nilai R square $\left(\mathrm{R}^{2}\right.$ ) (Wong, 2013). Hasil pengolahan data menunjukkan nilai $\mathrm{R}^{2}$ model penelitian ini adalah sebesar 0,815 untuk variabel Intensi dan 0,797 untuk variabel Perilaku. Hasil ini menunjukkan bahwa model intensi dijelaskan oleh pengetahuan dan sikap sebesar $81,5 \%$, sementara sisanya oleh variabel lain. Model perilaku pelaku usaha warung dalam penelitian ini dijelaskan oleh variabel pengetahuan, sikap dan intensi sebesar 79,7\%, sisanya dijelaskan oleh variabel lain.

\section{Hasil Uji Hipotesis}

Hasil pengujian hipotesis secara keseluruhan terlihat pada gambar 3 .

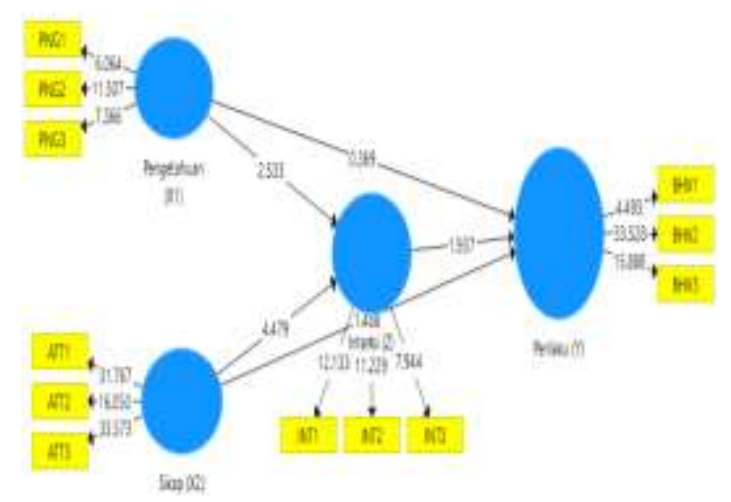

Gambar 3. Path Diagram Uji Hipotesis Sumber : Hasil pengolahan data, 2020

Gambar 3 menunjukkan nilai $\mathrm{t}$ statistic semua indikator dalam penelitian ini memiliki nilai lebih besar dari 1,96 (t tabel). Sehingga indikatorindikator tersebut mampu mengukur variabel pengetahuan, sikap, intensi, dan perilaku.

Hasil uji hipotesis antar variabel terlihat pada tabel 6.

Tabel 6. Pengujian Hipotesis

\begin{tabular}{|l|c|c|c|}
\hline $\begin{array}{c}\text { Hubungan Antar } \\
\text { Variabel }\end{array}$ & Koef. & $\begin{array}{c}\mathrm{T} \\
\text { stat. }\end{array}$ & Ket. \\
\hline $\begin{array}{l}\text { Pengetahuan } \\
\text { Intensi }\end{array}$ & 0,382 & 2,533 & Sig \\
\hline Sikap -> Intensi & 0,588 & 4,479 & Sig \\
\hline Intensi -> Perilaku & 0,516 & 1,937 & Sig \\
\hline $\begin{array}{l}\text { Pengetahuan -> } \\
\text { Perilaku }\end{array}$ & $-0,066$ & 0,369 & $\begin{array}{c}\text { Tdk } \\
\text { Sig }\end{array}$ \\
\hline Sikap -> Perilaku & 0,462 & 1,488 & Sig \\
\hline
\end{tabular}

Sumber : Hasil Pengolahan data, 2020

Wong (2013) menjelaskan signifikan hubungan antar variabel dalam output SmartPLS adalah dilihat dari nilai koefisien. Signifikansi terjadi ketika nilai koefisien lebih dari 0,10. 
Tabel 6 menunjukkan jawaban untuk hipotesis dalam penelitian ini. Hipotesis 1, adanya pengaruh positif dan signifikan secara langsung antara variabel pengetahuan dan intensi. Hasil uji hipotesis menunjukkan nilai koefisien lebih dari 0,10 , sehingga hipotesis pertama dapat diterima. Hipotesis 2, 3, 5, dan 6 juga dapat diterima, karena nilai koefisien hubungan antar variabel lebih besar dari 0,10 . Hipotesis 6 terlihat dari nilai koefisien intensi terhadap perilaku lebih besar dari 0,1 yaitu 0,516, bahwa adanya pengaruh positif dan signifikan variabel pengetahuan dan sikap secara tidak langsung terhadap variabel perilaku melalui variabel intensi. Hipotesis 4 tidak diterima, karena nilai koefisien hubungan antara pengetahuan terhadap perilaku lebih kecil dari 0,10 yaitu sebesar 0,066 dan hubungan yang terbentuk adalah negative.

\section{Pembahasan}

Pendapatan pelaku usaha warung mengalami penurunan selama pandemic covid 19, hal ini sesuai dengan penelitian Awali \& Rohmah (2020), Hanoatubun (2020), Hardilawati (2020), dan Shofiana (2020).

Hasil uji hipotesis menunjukkan bahwa pengetahuan dan sikap dapat mempengaruhi perilaku anggota kelompok usaha warung sejahtera secara tidak langsung melalui intensi anggota. Hasil ini sesuai dengan hasil penelitian Maulana (2020) bahwa makin banyak informasi yang diterima seseorang dan membentuk pengetahuan, maka makin besar munculnya kepercayaan seseorang tersebut. Penelitian Kurniaputri et al. (2020) juga menghasilkan signifikansi antara intensi terhadap perilaku.

Penelitian ini menghasilkan bahwa tingkat pengetahuan pelaku usaha warung mengenai digital marketing yang termasuk dalam kategori cukup mengetahui tidak berpengaruh positif dan signifikan secara langsung terhadap perilaku anggota kelompok usaha warung sejahtera dalam menerapkan digital marketing. Pengetahuan pelaku usaha warung mengenai digital marketing lebih banyak tentang jenis-jenis platform digital marketing, bukan mengenai manfaat digital marketing tersebut. Hal ini jika dihubungkan secara langsung terhadap perilaku belum memberikan dampak yang signifikan, harus melalui intensi. Intensi pelaku usaha warung berupa kepercayaan mengenai manfaat digital 
marketing, sehingga pelaku usaha warung dapat menerapkan digital marketing dalam memasarkan produk.

Kegiatan pengabdian masyarakat ini memberikan gambaran mengenai para pelaku usaha warung yang termasuk kategori UMKM dalam hal tingkat pengetahuan, sikap, intensi dan perilaku penerapan digital marketing. Tingkat pengetahuan pelaku usaha warung belum tinggi dalam hal manfaat dari digital marketing. Sikap pelaku usaha warung juga belum banyak yang akan memanfaatkan digital marketing dalam jalanin usaha warung. Hasil ini berdampak kepada intensi pelaku usaha warung untuk menggunakan digital marketing dan juga perilaku anggota kelompok usaha warung sejahtera.

$$
\text { Keyakinan para pelaku usaha }
$$
warung yang belum tinggi dalam menerapkan digital marketing salah satu penyebabnya adalah kepemilikan smartphone. Smartphone merupakan perangkat minimal yang harus dimiliki untuk mengoptimalkan digital marketing.

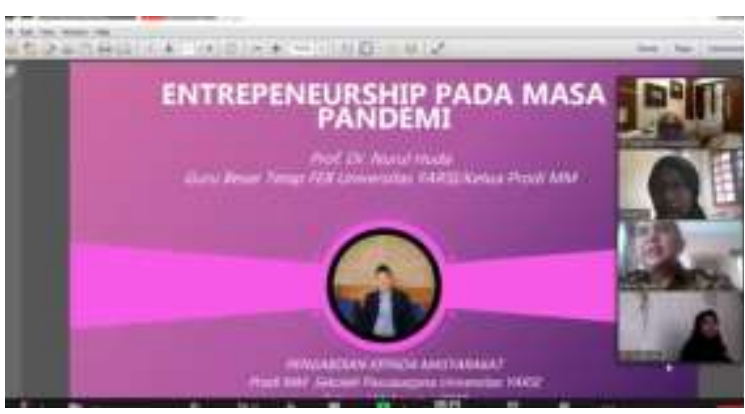

Gambar 4. Suasana Pelatihan Via Zoom

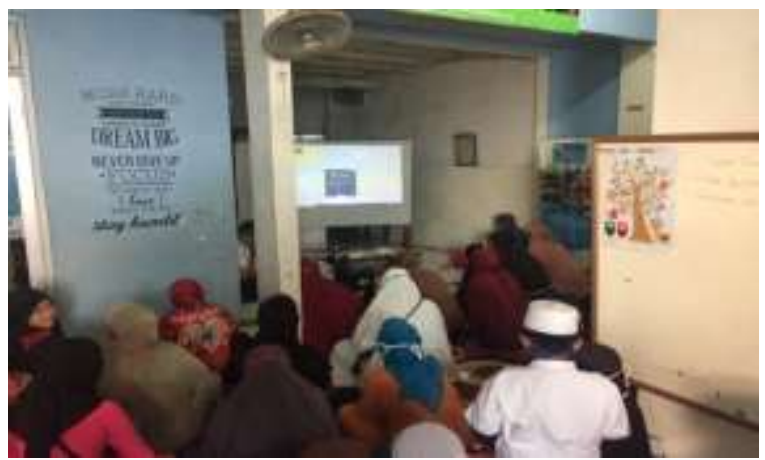

Gambar 5. Suasana Pelatihan Online di Mitra

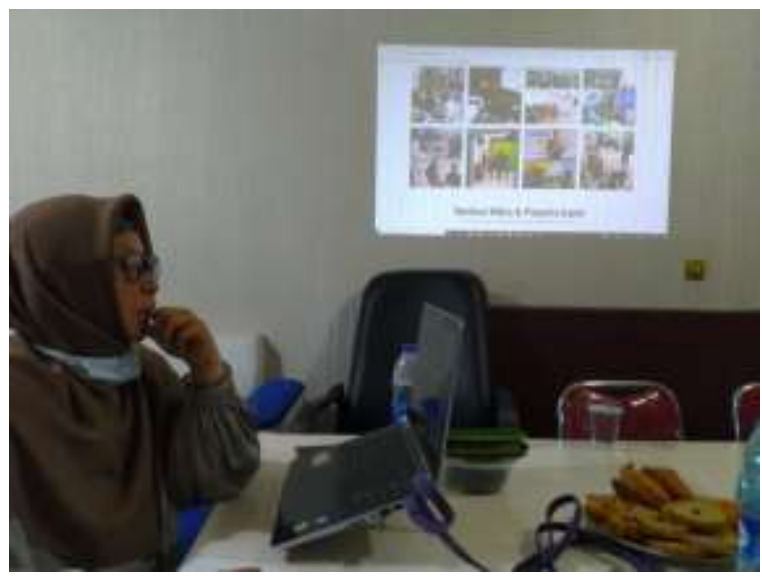

Gambar 6. Suasana pendampingan di

Mitra

\section{KESIMPULAN}

Kesimpulan hasil kegiatan pengabdian masyarakat ini berupa intensi dan perilaku anggota kelompok usaha warung sejahtera menggunakan digital marketing dalam jalanin usaha. Intensi dan perilaku anggota Kelompok Usaha Warung Sejahtera cukup tinggi untuk menerapkan atau menggunakan digital marketing dalam meningkatkan pendapatan. Hal ini terlihat dari hasil uji hipotesis yang signifikan antara 
pengaruh pengetahuan dan sikap secara tidak langsung terhadap perilaku melalui variabel intensi pelaku usaha warung.

\section{ACKNOWLEDGEMENTS}

We thank to Directorate of General for Strengthening Research and Development, the Ministry of Research and Technology Republic Indonesia, Higher Education (DIKTI) for providing this research

\section{DAFTAR PUSTAKA}

Adhania, L. S. O. (2017). Peningkatan Pendapatan Pelaku Usaha Warung Wedang Kopi Desa Karangsari Kecamatan Sukodono Kabupaten Lumajang. Warta Pengabdian, 11(1), 253$262 . \quad$ https://doi.org/doi: 10.19184/wrtp.v12i1.7456

Ajzen, I. (1991). The Theory of Planned Behavior. Organizational Behavior And Human Decision Processes, 50, 179-211.

Ajzen, I., \& Fishbein, M. (1977). Attitude-Behavior Relations: A Theoretical Analysis and Review of Empirical Research. Psychological Bulletin, 84(5), 888-918.

Awali, H., \& Rohmah, F. (2020). Urgensi Pemanfaatan EMarketing Pada Keberlangsungan UMKM di Kota Pekalongan di Tengah Dampak Covid-19. BALANCA : Jurnal Ekonomi dan Bisnis Islam, $\quad 2(1), \quad 1-14$. https://doi.org/10.35905/balanca .v2i1.1342

Conner, M., \& Norman, P. (2005). Predicting Health Behaviour (Second). Open University Press.

Danim, S. (2007). Metode Penelitian Untuk Ilmu-Ilmu Prilaku (Cetakan ke 4). PT. Bumi Aksara.

Dewi, N. K. A. T., Astawa, I. B. M., \& Suditha, I. N. (2014). Dampak Minimarket Terhadap Eksistensi Warung Tradisional di Kota Singaraja. Jurnal Pendidikan Geografi Undikhsa, 2(3), 1-12. http://dx.doi.org/10.23887/jjpg.v 2i3.20426

Ghozali, M. (2005). PLS-Partial Least Square (Structural Equation Modeling). Universitas Diponegoro.

Hanoatubun, S. (2020). Dampak Covid19 Terhadap Perekonomian Indonesia. EduPsyCouns: Journal of Education, Psychology and Counseling, 2(1), 146-153.

Hardilawati, W. laura. (2020). Strategi Bertahan UMKM di Tengah Pandemi Covid-19. Jurnal Akuntansi dan Ekonomika, 10(1), 89-98. https://doi.org/10.37859/jae.v10i 1.1934

Huda, N., \& Nazwirman, N. (2018). Pengembangan Kelompok Usaha Mandiri Masyarakat (KUMM) Menuju Koperasi Syariah. JURNAL PENGABDIAN AL-IKHLAS, 3(2), 130-142. https://doi.org/10.31602/jpai.v3i 2.1261 
Huda, N., Nazwirman, N., \& Hulmansyah, H. (2018). Pembinaan Organisasi Kelompok Usaha Mandiri Masyarakat (KUMM) Berbasis Akuntabilitas dan Islami. Jurnal Pengabdian Al-Ikhlas, 2(2), 3041.

https://doi.org/10.31602/jpai.v2i 2.755

Huda, N., Rini, N., Mardoni, Y., \& Putra, P. (2012). The Analysis of Attitudes, Subjective Norms, and Behavioral Control on Muzakki's Intention to Pay Zakah. International Journal of Business and Social Science, 3(22), 271-279.

Huda, N., Zulihar, Z., \& Hulmansyah, H. (2020). Manajemen Pengelolaan Zakat Bagi Pengurus Masjid. Jurnal Pengabdian Al-Ikhlas, 6(1), 7385.

Imron, M., \& Wibowo, P. A. (2008). Analisis Faktor-Faktor Yang Mempengaruhi Tingkat Keberhasilan Usaha (Studi pada Warung "Nasi Kucing" di Kabupaten Jepara). JURNAL DINAMIKA EKONOMI \& BISNIS, 5(2), 111-132.

Kurjono, \& Setiawan, Y. (2020). Pengaruh Kontrol Perilaku Yang Dirasakan dan Norma Subyektif Terhadap Intensi Berwirausaha Dimediasi Sikap Kewirausahaan. Jurnal Ilmu Manajemen Dan Bisnis, 11(1), 81-97.

Kurniaputri, M. R., Dwihapsari, R., Huda, N., \& Rini, N. (2020). Intensi Perilaku dan Religiusitas Generasi Millenials Terhadap Keputusan Pembayaran ZIS Melalui Platform Digital. $E$ -
QIEN: Jurnal Ekonomi Dan Bisnis, $\quad 7(2), \quad$ 15-22. https://doi.org/10.34308/eqien.v $7 \mathrm{i} 2.134$

Mahyarni, M. (2013). Theory Of Reasoned Action Dan Theory Of Planned Behavior (Sebuah Kajian Historis tentang Perilaku). Jurnal EL-RIYASAH, 4(1), 13-23. https://doi.org/10.24014/jel.v4i1 .17

Maulana, I. (2020). Peran Pengetahuan Konsumen, Keterlibatan Konsumen, Dan Faktor Psikologis Konsumen Pada Intensi Beralih Pelanggan Department Store Purwakarta Ke Belanja Daring. E-QIEN: Jurnal Ekonomi Dan Bisnis, 7(2), 49-51. https://doi.org/10.34308/eqien.v $7 \mathrm{i} 2.138$

Mutmainah, N. F. (2020). Peran Perempuan Dalam Pengembangan Ekonomi Melalui Kegiatan UMKM di Kabupaten Bantul. Jurnal Wedana, VI(1), 1-7. https://doi.org/10.25299/wedana .2020.vol6(1).4190

Ompusunggu, M. P., \& Djawahir, A. H. (2014). Gaya Hidup dan Fenomena Perilaku Konsumen pada Warung Kopi di Malang. Jurnal Aplikasi Manajemen, 12(2), 188-196.

Purnama, F., Putrawan, I. M., \& Sigit, D. V. (2020). Pengaruh Pengetahuan Mengenai Isu-Isu Lingkungan (Knowledge About Environmental Issues) dan Intensi Untuk Bertindak (Intention to Act) terhadap Perilaku Bertanggung Jawab Lingkungan (Responsible 
Environmental Behavior) Siswa. IJEEM - Indonesian Journal of Environmental Education and Management, 5(1), 20-33. https://doi.org/10.21009/IJEEM. 051.02

Shofiana, A. (2020). Implementasi Program Afiliasi Berbasis Virtual Team dalam UMKM Sebagai Upaya Peningkatan Perekonomian Pada Masa Pandemi Covid-19. SSRN Electronic Journal, 10. https://dx.doi.org/10.2139/ssrn.3 590822
Simamora, B. (2002). Panduan riset perilaku konsumen. Gramedia Pustaka Utama.

Venkatesh, V., Morris, M. G., Davis, G. B., \& Davis, F. D. (2003). User Acceptance of Information Technology: Toward a Unified View. MIS Quarterly, 27(3), 425-478.

https://doi.org/10.2307/3003654 0

Wong, K. K.-K. (2013). Partial Least Squares Structural Equation Modeling (PLS-SEM) Techniques Using SmartPLS. Marketing Bulletin, 24(1), 1-32. 